\title{
GOLD NANOPARTICLES MODIFIED SCREEN PRINTED CARBON ELECTRODE AS A TOOL FOR DETECTION OF TP53
}

\author{
1'Zuzana KOUDELKOVÁ, ${ }^{1,2}$ Eliška SEDLÁČKOVÁ, ${ }^{1,2}$ Lukáš RICHTERA, ${ }^{1}$ Pavel ŠVEC, \\ 1,2Vojtěch ADAM \\ ${ }^{1}$ Department of Chemistry and Biochemistry, Mendel University in Brno, Czech Republic, EU \\ ${ }^{2}$ Central European Institute of Technology, Brno University of Technology, Brno, \\ Czech Republic, EU
}

https://doi.org/10.37904/nanocon.2019.8611

\begin{abstract}
Cancer is one of the most common causes of death in developing countries and in the developed world. The function of the p53 protein plays an important role in the development of cancer. The protein p53 regulates the expression of genes that are responsible for the control of cell growth, apoptosis or for repair of damaged DNA. It $t$ is encoded by the tumor suppressor gene TP53. If this gene mutates, its product will be damaged. It was found that mutations in the TP53 gene is present in more than $50 \%$ of cancer cases. Electrochemical biosensors have proved to be a suitable method for the detection of TP53 and also its mutations. Electrochemical deposition of gold nanoparticles on the surface of working electrode increases the active surface area of the sensor, this leads to a more sensitive detection of the TP53 gene and its mutations. By developing an electrochemical biosensor based on gold nanoparticles modified screen printed electrodes, an efficient platform for detecting the TP53 gene in biological samples is obtained.
\end{abstract}

Keywords: Screen printed electrode, gold nanoparticles, gene TP53, protein p53, electrochemistry

\section{INTRODUCTION}

The TP53 gene is located on the 17th chromosome (specifically at the 17p13.1 locus). It is known as the guardian of the genome, because there just occur most somatic mutations, which result in malfunction of the gene products. It is reported that mutations in the TP53 gene is present in more than $50 \%$ of cancer cases [1]. The main product of the TP53 gene is the p53 protein that controls cell proliferation. The p53 protein is also involved in the maintenance of cellular homeostasis and in complex regulatory interactions [2]. Normally, the level of TP53 in cells is relatively low [3,4]. Cancer is one of the most common diseases of the world, early cancer diagnosis reduces mortality by several tens of percent. The rapid and specific recognition and quantitative detection of the TP53 gene is extremely important for basic research and early treatment of cancer [5-7].

The aim of the present work is to develop sensitivity electrochemical DNA biosensor for the determination of gene TP53 on gold nanoparticles using methylene blue (MB) as an electrochemical indicator. The deposition of gold nanoparticles on the surface of working electrode enlarge function surface of the electrode and improve its sensitivity.

\section{MATERIALS AND METHODS}

\subsection{Chemicals}

All chemicals were obtained from Sigma-Aldrich (St. Louis, MO, USA). High purity deionized water (Milli-Q Millipore $18.20 \mathrm{M} \Omega / \mathrm{cm}$, Bedford, MA, USA) was used throughout the study. 


\subsection{Gold nanoparticles fabrication}

All electrochemical experiments were performed with a potentiostat (Autolab PGSTAT 101, Metrohm, Herisau, Switzerland). An $\mathrm{Ag} / \mathrm{AgCl} 3 \mathrm{M} \mathrm{KCl}$ as a reference electrode and platinum electrode was auxiliary. Electrochemical software NOVA 2.1 (Metrohm, Herisau, Switzerland) was used for data evaluation. The surface of the screen printed carbon working electrode (SPCWE) was before each measurement modified in situ with gold nanoparticles. The SPCWE were immersed into solution $6.0 \mathrm{mM} \mathrm{HAuCl} 4$ and $0.1 \mathrm{M} \mathrm{KNO}$. The gold nanoparticles were deposited on the electrode surface using constant potential $-0.4 \mathrm{~V}$ for $900 \mathrm{~s}$. The working electrode was then rinsed with distilled water and dried under a nitrogen stream.

\subsection{Preparation of electrochemical biosensor}

On the surface modified SPCWE was applied $5.0 \mu \mathrm{l}$ sSDNA ([ThiC6] GGC ACA CAC CTC AAC ACG AA). Immobilization was carried out for 12 hours at $4^{\circ} \mathrm{C}$. After immobilization followed rinsing the SPCWE with $0.2 \mathrm{M}$ phosphate buffer (PB) with $\mathrm{pH} 7$.

The first step of hybridizing was blocking the free binding sites with $1 \mathrm{mM} 6$-mercapto-1hexanol for 1 hour. The electrode was then rinsed with PB again. After this was on the electrode applied the complementary strand of DNA (TT GAG GTG CGT GTT TGT GCC) and incubated for 1 hour at $37^{\circ} \mathrm{C}$.

\subsection{Electrochemical determination of gene TP53}

The modified electrodes were immersed in $10 \mathrm{mM}$ methylene blue (MB) for 10 minutes. Then they were washed with $20 \mathrm{mM}$ PB. Electrochemical determination was performed by differential pulse voltammetry (DPV) with the following parameters: initial potential of $0 \mathrm{~V}$, end potential $-0.4 \mathrm{~V}$, step $-5 \mathrm{mV}$, modulation amplitude $25 \mathrm{mV}$, modulation time $50 \mathrm{~ms}$, interval time $0.5 \mathrm{~s}$. As supporting electrolyte was used PB pH 7.

\section{RESULT AND DISCUSSION}

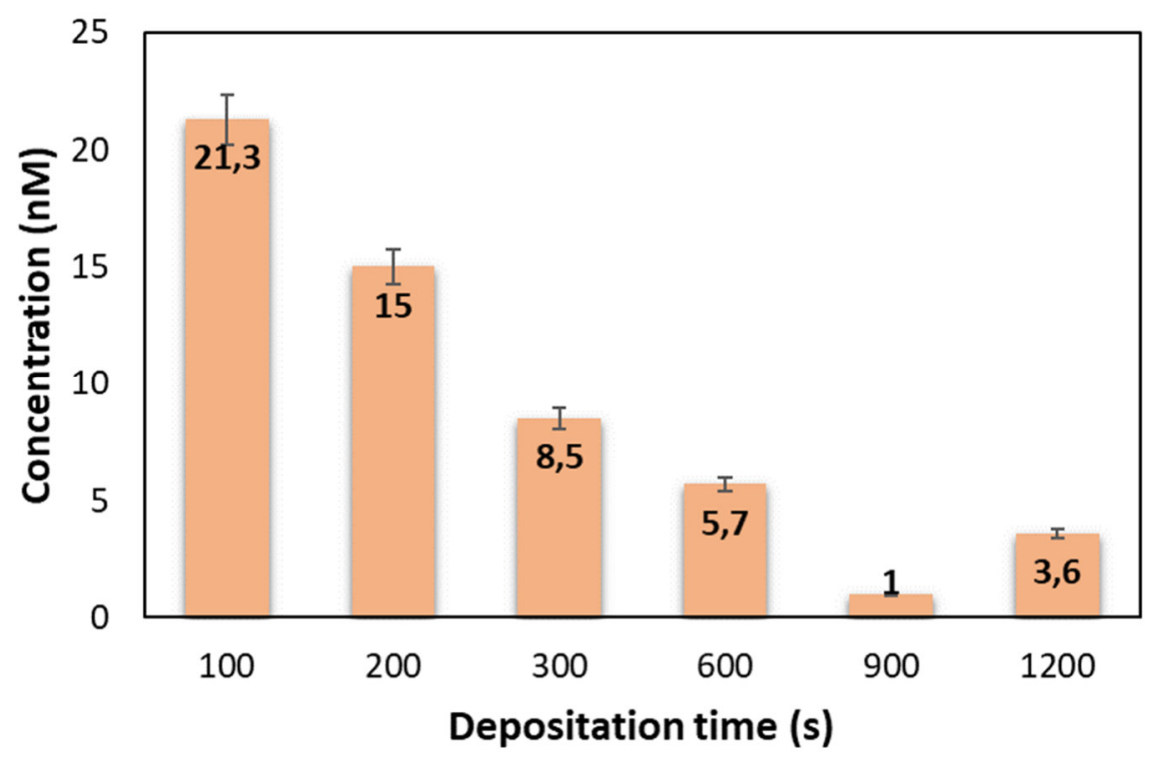

Figure 1 Optimization of time deposition of gold nanoparticles on the electrode surface in dependence on the lowest detectable concentration

Obviously, deposition time influences the current response of the analyte and stability of the biosensor. The Figure 1 shows the optimization of the deposition time, which affects the formation of different sizes of gold 
nanoparticles. As an optimal deposition time was chosen $900 \mathrm{~s}$, which was achieved at the lowest limit of detection of complementary DNA. With a higher deposition time, the saturation capacity of SPCWE is reached.

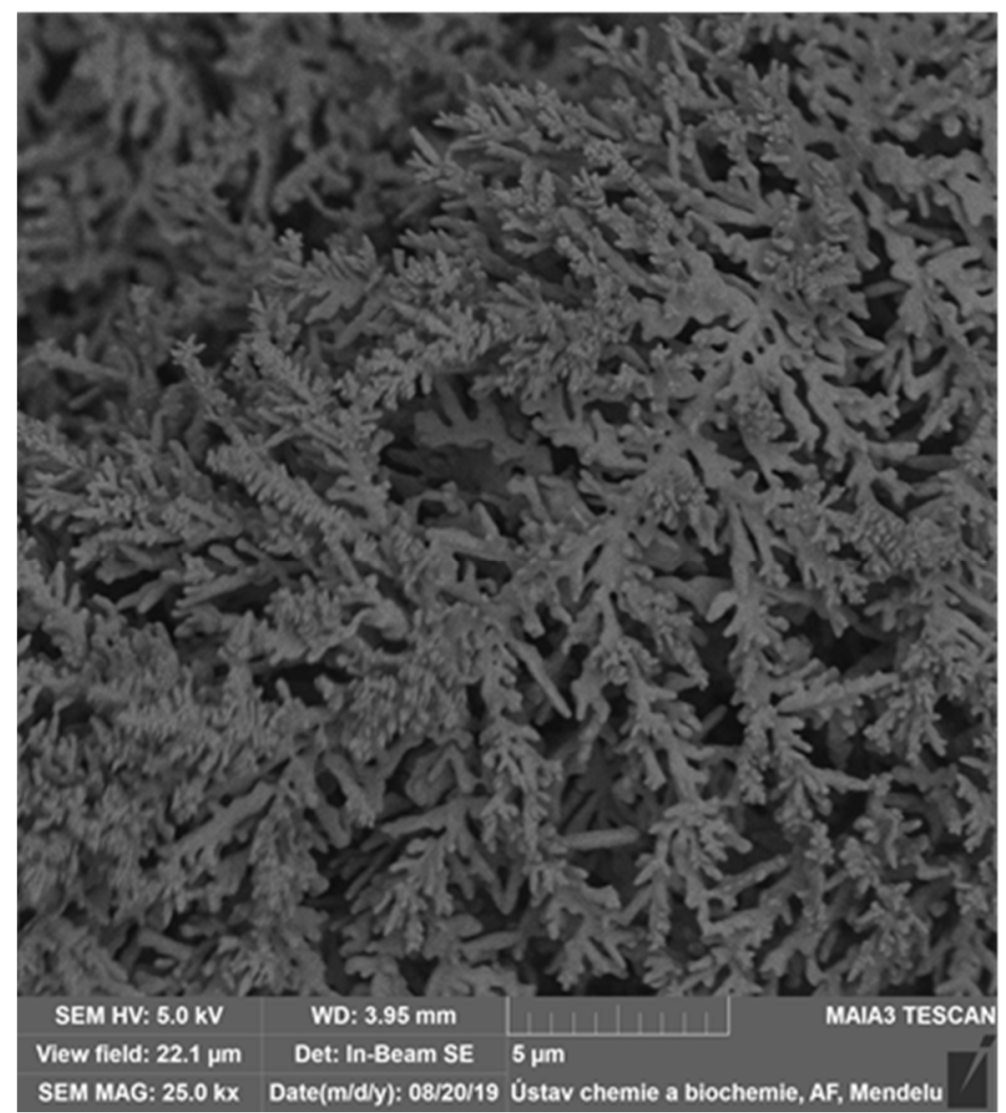

Figure 2 SEM characterization of gold nanoparticles modified SPCWE

In the Figure 2 shows the structure of gold nanoparticles which were produced by electrochemical deposition on the SPCWE surface. On the electrode is formed of gold "shrubby structures" that are branched into space. With these gold structures increased active surface of the working electrode.

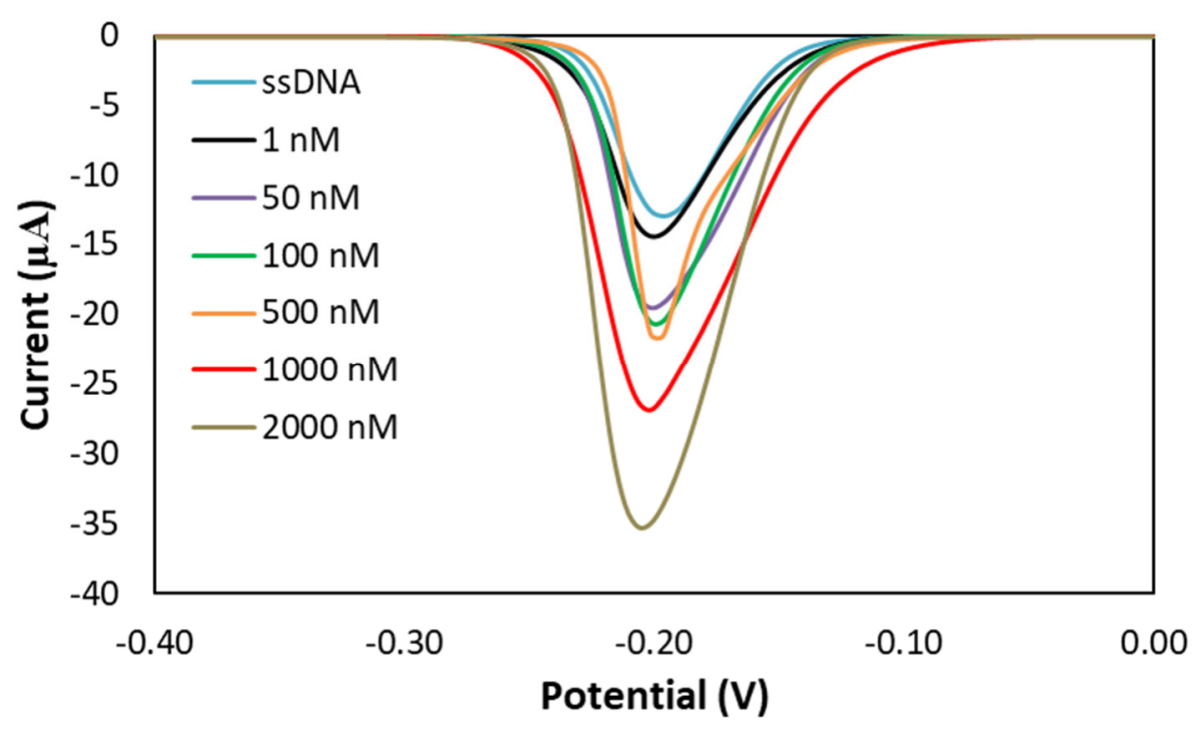

Figure 3 Differential pulse voltammogram of the gold nanoparticles modified SPCWE for detectionTP53 
Under the optimal conditions, the biosensor was hybridized with different concentrations of the complementary DNA sequence and the reduction peak current of MB was measured. A typical DPV record with concentrations is shown in Figure 3. The lowest measured concentration was $1 \mathrm{nM}$.

\section{CONCLUSION}

In conclusion, the new modification of working electrode for determination of TP53 was developed. This modification allows to measure the concentration of the TP53 gene in the physiological range with limit of detection $1 \mathrm{nM}$. Normally the level of TP53 is very low and due to the cancer proliferation the level of TP53 is increasing. Determination of TP3 gene concentration is important for early detection of cancer.

\section{ACKNOWLEDGEMENTS}

The research was financially supported by the IGA MENDELU AF-IGA2019-IP059 and was carried out under the project CEITEC 2020 (LQ1601) with financial support from the Ministry of Education, Youth and Sports of the Czech Republic under the National Sustainability Programme II.

\section{REFERENCES}

[1] PALECEK, E., CERNOCKA, H., OSTATNA, V., NAVRATILOVA, L., BRAZDOVA, M., Electrochemical sensing of tumor suppressor protein p53-deoxyribonucleic acid complex stability at an electrified interface. Analytica chimica acta. 2014. 828: p. 1-8.

[2] HASANZADEH, M., SHADJOU, N., DE LA GUARDIA, Current advancement in immunosensing of p53 tumor suppressor protein based on nanomaterials: Analytical approach. TrAC Trends in Analytical Chemistry. 2017. 89: p. $13-20$

[3] WANG, X., ZHANG, X., HE, P., FANG, Y., Sensitive detection of p53 tumor suppressor gene using an enzymebased solid-state electrochemiluminescence sensing platform. Biosensors and Bioelectronics. 2011. 26(8): p. 3608-3613.

[4] RAOOF, J.B., OJANI, R., GOLABI, S. M., HAMIDI-ASL, E., HEJAZI, M. S., Preparation of an electrochemical PNA biosensor for detection of target DNA sequence and single nucleotide mutation on p53 tumor suppressor gene corresponding oligonucleotide. Sensors and Actuators B: Chemical. 2011. 157(1): p. 195-201.

[5] XIAN-WEN, L., FANG-JING, D. U., YE, W. U., LOU-JUN, G. A. O., XIAO-XIA, L. I. et al., Electrochemical DNA sensor for determination of p53 tumor suppressor gene incorporating gold nanoparticles modification. Chinese Journal of Analytical Chemistry. 2013. 41(11): p. 1664-1668.

[6] LIU, S., Liu, J., WANG, L., ZHAO, F., Development of electrochemical DNA biosensor based on gold nanoparticle modified electrode by electroless deposition. Bioelectrochemistry. 2010. 79(1): p. 37-42.

[7] HASANZADEH, M., BAGHBAN, H. N., SHADJOU, N., MOKHTARZADEH, A., Ultrasensitive electrochemical immunosensing of tumor suppressor protein p53 in unprocessed human plasma and cell lysates using a novel nanocomposite based on poly-cysteine/graphene quantum dots/gold nanoparticle. International journal of biological macromolecules. 2018. 107: p. 1348-1363. 